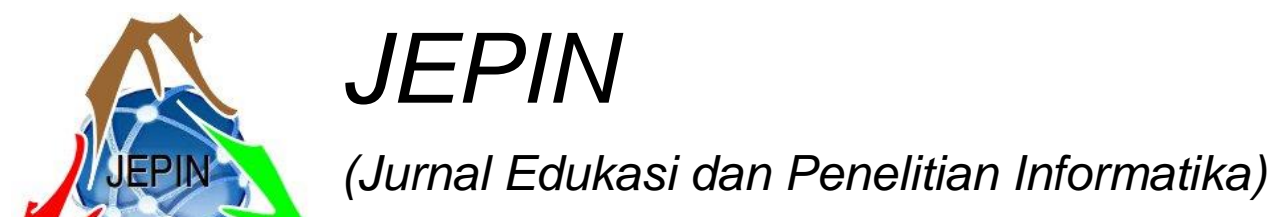

Vol. 6

No. 2

ISSN(e): 2548-9364 / ISSN(p) : 2460-0741

\title{
Analisis Perbandingan Kualitas UI/UX Platform Online Coding Course pada Pembelajaran Daring Pemrograman Komputer dengan Metode A/B Testing
}

\author{
Novia Ratnasari $^{\# 1}$, Aji Prasetya Wibawa ${ }^{\# 2}$ \\ \#Program Pascasarjana Pendidikan Kejuruan, Universitas Negeri Malang \\ Jl. Semarang No.5, Gedung H5 Fakultas Teknik, Kec. Lowokwaru, Kota Malang \\ ${ }^{1}$ novia.ratnasari.19055180.students.um.ac.id \\ 2aji.prasetya.ft@um.ac.id
}

\begin{abstract}
Abstrak - Dalam Era Industri 4.0, siswa SMK harus mampu menguasai berbagai jenis bahasa pemrograman dengan mengikuti perkembangan teknologi dan informasi yang dibutuhkan dalam dunia industri. Namun, hal ini berbanding arah dengan sinkronisasi kurikulum pada Sekolah Menengah Kejuruan. Pada konsentrasi pemrograman hanya terdapat beberapa bahasa pemrograman seperti JAVA, PHP, dan C++ dengan kompetensi keahlian dasar sebagai bentuk bekal peserta didik belajar bahasa pemrograman dasar. Untuk itu peserta didik perlu melakukan upgrade skills coding yang dimiliki dengan terus mempelajari bahasa pemrograman dari banyak sumber. Antara lain adalah online coding course Codecademy; W3school; dan Udemy, yang menjadi wadah bagi siswa untuk mengasah kemampuan coding diluar jam pelajaran efektif. Pada penelitian ini dilakukan analisis user interface dan user exsperience berdasarkan $A / B$ testing dengan berpedoman pada $5 \mathrm{E}$ yaitu: a. Effective; b. Efficient; c. Engaging; d. Error Tolerant; dan e. Easy to Learn. Tujuan dari penelitian ini adalah untuk melakukan ekplorasi terhadap ketiga situs web tersebut. Hasil penelitian ini menyatakan bahwa kecenderungan siswa SMK lebih menggunakan situs W3school sebagai online coding course dengan presentase $130 \%$ atau rata-rata 1.30 poin. Hasil penelitian ini dapat digunakan sebagai acuan guru dan siswa dalam memilih sumber belajar, dan kepada developer dapat dijadikan rekomendasi market share pengguna yang disesuaikan dengan kebutuhan siswa SMK.
\end{abstract}

Kata kunci- online coding course, Codecademy, W3school, Udemy, Bahasa Pemrograman

\section{PEndahuluan}

Kemampuan pemrograman adalah salah satu kemampuan penting yang harus dimiliki oleh peserta didik di Era Industri 4.0. Beberapa bahasa pemrograman yang harus dikuasai oleh peserta didik adalah JAVA [1], C++ [2], Python [3], PHP, MySQL, dan JavaScript [4]. Kendala yang dihadapi adalah banyaknya ragam bahasa pemrograman yang digunakan oleh siswa SMK. Hal ini menjadi kendala dalam proses pembelajaran, khusunya bagi peserta didik [2]. Mereka akan dibebani untuk menguasai lebih dari satu bahasa pemrograman. Kendala yang kedua adalah kurikulum yang tidak bisa mengikuti laju perkembangan teknologi [5]. Berbagai kendala dalam proses pembelajaran harus mendapatkan stimulus yang tepat, karena kualitas dari sumberdaya manusia ditentukan oleh bagaimana kualitas Pendidikan yang diperoleh [6] Oleh karena itu, masalah ini harus dipecahkan sehingga, generasi kedepan memiliki keahlian dibidang pemrograman

Teknologi mampu menjadi trobosan dan inovasi dalam bidang pendidikan [7]. Teknologi dapat digunakan untuk mendukung pelaksanaan proses pembelajaran [8] Pemanfaatan teknologi dalam dunia pendidikan memberikan pengalaman belajar baru, ilmu baru, dan wawasan baru dari dunia luar [9]. Sumber belajar berbasis teknologi informasi dan komputer (TIK) mampu menepis permasalahan seperti minimnya jam pertemuan, keterbatasan sumber belajar, dan jarak yang jauh [10]. Salah satu model sumber belajar yang marak digunakan didunia pendidikan adalah sumber belajar berbasis web [11]. Sesuai dengan kurikulum Pendidikan SMK Kejuruan program rekayasa perangkat lunak, terdapat beberapa jenis kompetensi yang harus di kuasai, antara lain: 1). Program berorientasi objek; 2). Membuat aplikasi web stateful; dan 3). Membuat aplikasi sederhana berbasis antar muka [12]. Selaras dengan kurikulum PSMK, Jerrad mengungkapkan terdapat beberapa learning code yang dapat digunakan sebagai sumber belajar online coding course yang mencakup tiga keahlian tersebut[13], antara lain: Codecademy [14]; W3school [15]; dan Udemy [16]. Ketiga Platform memiliki keunggulan yang berbeda-beda. Artikel ini bertujuan untuk melakukan ekplorasi terhadap ketiga situs web tersebut. Ketiganya akan dibandingkan dalam hal, user interface dan user experience. Hasil 
penelitian ini digunakan sebagai acuan dalam memilih sumber belajar dilingkungan Pendidikan kejuruan khususnya bagi guru dan siswa SMK, ataupun dapat digunakan developer untuk mengembangkan dan menambahkan fasilitas pada aplikasi yang dapat disesuaikan dengan kebutuhan siswa SMK.

\section{MetODE}

Penelitian ini dilakukan secara observasi online, membuat checklist tentang konten, dan melibatkan user sebagai koresponden. Periode pengamatan penelitian ini dilakukan selama 1 minggu dengan jumlah responden sebanyak 10 siswa SMK, terdiri dari 5 siswa SMK jurusan RPL dan 5 siswa SMK jurusan non RPL. Metode penelitian yang digunakan adalah Literatur Review, dan A/B testing (Gambar1) [17]. A/B testing merupakan tahapan evaluasi dengan 5 tahapan, antara lain [18][19]: 1. Set Your Goal; 2. Decide What to Test; 3. Create Variations; 4. Run Test; 5. Analyze Your Results; 6. Repeat.

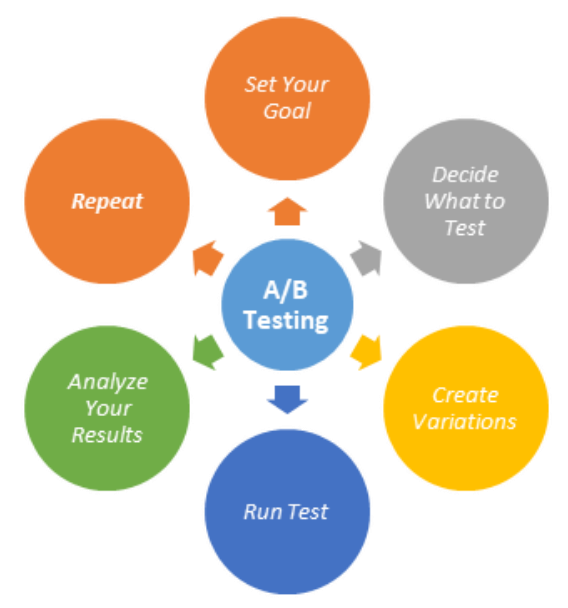

Gambar 1. A/B Testing

\section{A. Set Your Goal}

Dalam penelitian ini membandingkan 3 alamat web online coding course berdasarkan fitur-fitur yang terdapat pada Website online coding course, agar dapat digunakan sebagai acuan pembelajaran atau sebagai sumber belajar dan dapat digunakan sebagai acuan pengembang atau developer untuk mengembangkan sistem informasi berbasis Website dengan fitur yang lebih baik.

\section{B. Decide What to Test}

Sistem informasi berbasis Website yang akan dijadikan objek dalam penelitian ini memiliki beberapa fitur dan karakteristik yang berbeda, maka dari itu diperlukan suatu test sebagai dasar analisis dengan pendekatan 5Es, yaitu sebagai berikut:

- Effective

- Efficient

- Engaging

- Error Tolerant

- Easy to Learn [20].

\section{Create Variations}

Pada tahapan membuat variasi dalam membandingkan 3 Website, dipenelitian ini menggunakan tools berupa https://trends.google.com. Dengan melakukan perbandingan data dari 5 tahun terakhir serta memperhatikan masing-masing dari kategori-kategori yang termasuk dalam cakupan online coding course. Kategori-kategori tersebut, antara lain:

- Umum

- Job \& Education

- Business \& Industrial

- Computer \& Electronic

\section{Run test}

Pada tahapan selanjutnya adalah proses metode penelitian Run Test, dengan membuat sebuah angket berisikan point dalam pendekatan 5Es dengan tahapan sebagai berikut:

1) Membuat Instrumen Penilaian: Pembuatan instrument menggunakan pedoman yang diadaptasi dari Quesenbery dengan pendekatan 5Es, yaitu sebagai berikut: a. Effective: $b$. Efficient; $c$. Engaging; d. Error Tolerant; dan e. Easy to Learn [20] yang dikembangkan menjadi instrument yang dapat dilihat pada Tabel 1.

TABEL I

KATEGORI OBSERVASI

\begin{tabular}{|c|c|c|}
\hline Category & Codecademy & Soal \\
\hline \multirow{4}{*}{$\begin{array}{l}\text { Effective } \\
\text { (Respon } \\
\text { time) }\end{array}$} & Waktu loading Website & \multirow[t]{4}{*}{5 Soal } \\
\hline & Responsibility & \\
\hline & Kecepatan Compiler & \\
\hline & Fasilitas Free Trial & \\
\hline \multirow[t]{6}{*}{ Efficient } & Desain Halaman Depan & \multirow[t]{6}{*}{6 Soal } \\
\hline & Alternatif Akun Login & \\
\hline & Halaman Login & \\
\hline & Warna Website & \\
\hline & Project Develop & \\
\hline & Contoh Koding & \\
\hline \multirow[t]{5}{*}{ Engaging } & $\begin{array}{l}\text { Jenis Pilihan Penggunaan } \\
\text { Bahasa } \\
\text { (JAVA, C++, Python, PHP, } \\
\text { MySQL, dan JavaScript) }\end{array}$ & \multirow[t]{5}{*}{5 Soal } \\
\hline & Jenis Bahasa Pemrograman & \\
\hline & Jenis katalog Harga & \\
\hline & Jenis Pembayaran Gratis & \\
\hline & Jenis Exercises & \\
\hline $\begin{array}{l}\text { Error } \\
\text { Tolerant }\end{array}$ & Error Enkripsi & 1 Soal \\
\hline \multirow[t]{2}{*}{$\begin{array}{l}\text { Easy to } \\
\text { Learn }\end{array}$} & Tombol Help & \multirow[t]{2}{*}{2 Soal } \\
\hline & Lesson Guide & \\
\hline
\end{tabular}

2) Melakukan Uji Coba Pengguna

Uji coba A/B Testing dilakukan oleh dua kelompok responden dengan latar belakang yang berbeda yaitu:

- Responden Uji Coba Kelompok Expert Person Informatika dilakukan oleh 5 Siswa SMK 
- Responden Uji Coba Kelompok Non Informatika dilakukan oleh 5 Siswa SMK

Uji coba dilakukan dengan cara melakukan pengisian angket analisis uji coba, dan dilakukan perhitungan skor yang diperoleh melalui aplikasi Google Form yang sudah dimodifikasi.

\section{E. Analyze Your Result}

Dari hasil uji coba menggunakan metode A/B testing serta tools Google Form untuk mengetahui minat dan respon user dapat dilakukan analisis dengan metode komparasi dua bidang keahlian yang berbeda, yaitu dibagi atas kelompok expert dan kelompok non expert. Hal ini dilakukan untuk mengetahui sejauh mana pengalaman user dengan background yang berbeda dan keahlian yang berbeda tentang presepsi user terhadap online coding course.

\section{F. Repeat}

Dari hasil analisis melalui tools google trend dan Google Form, dapat dijadikan pedoman dalam melakukan analisis dan observasi secara berkala, agar developer dapat memperbaiki kualitas sistem informasi dan dari sisi Pendidikan dapat dimanfaatkan sebagai bahan ajar yang adaptif bagi peserta didik.

\section{HASIL DAN PEMBAHASAN}

Ketertarikan baru dalam dunia pemrograman yaitu lingkungan belajar mengajar berbasis web, salah satunya adalah situs codecademy yang merupakan online course programming dengan jumlah anggota lebih dari 25 juta di seluruh dunia [21]. Selain itu, W3school adalah sebuah situs penyedia informasi dan tutorial serta referensi yng berkaitan dengan beberapa bahasa pemrograman web seperti HTML, CSS, Java Script, PHP, SQL [22]. Bagaimana proses perekrutan sebuah pekerjaan berdasarkan keterampilan dan pengetahuan sebagai pekerja professional, untuk membekali para pekerja dengan kemampuan yang dibutuhkan industri, salah satunya dapat menggunakan situs Udemy[23]. Pada penelitian ini, seperti yang dijabarkan pada tahap metode penelitian akan menggunakan A/B Testing dengan hasil sebagai berikut.

Pada chart google trend (Gambar 2), diperoleh data bahwa di Negara Indonesia pada kurun waktu 5 tahun terakhir diperoleh:

1) Website W3Schools lebih mendapat minat dihati masyarakat dengan presentase grafik meningkat dengan jumlah data responden 14.125.

2) Website Udemy mendapat peringkat kedua dengan jumlah responden 4.015.

3) Kemudian pada urutan ketiga Website Codecademy memperoleh responden sejumlah 2.180.

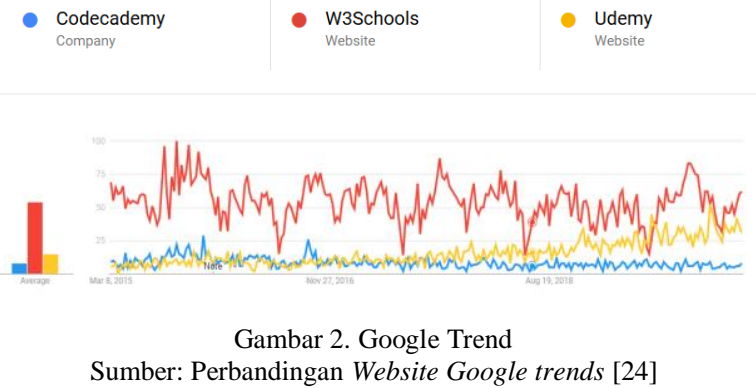

Dari data google trend juga diperoleh kategori keminatan masyarakat berdasarkan Job \& Education dari masing-masing Website pada kurun waktu 5 tahun terakhir diperoleh dapat dilihat pada Gambar 3.

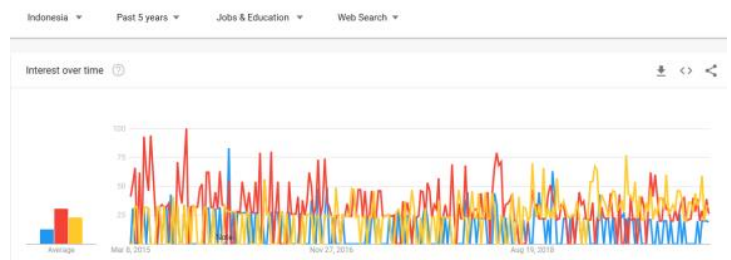

Gambar 3. Google trends by Job \& Education

Sumber: Perbandingan Website Google trends by Job \& Education[24]

Kesimpulan google trend dikembangkan sesuai hasil grafik dan didukung oleh literasi sebagai berikut:

1) Pada kategori Job \& Education Website yang paling sering digunakan adalah web site W3Schools dengan jumlah responden sejumlah 7.956 .

2) Website kedua dengan kategori Job \& Education paling sering digunakan adalah Website Udemy dengan jumlah responden 5.882 .

3) Website codecademy merupakan Website dengan jumlah paling rendah pada kategori Job \& Education dengan total pengunjung 3.258 responden.

4) Dapat diperoleh bahwa Website online course coding sangat diminati oleh masyarakat dan dimanfaatkan dalam bidang pendidikan dan pekerjaan pada 5 tahun terakhir, dibuktikan dengan jumlah responden pada masing-masing Website stabil dan mengalami peningkatan

5) Hal ini juga disebabkan karena W3School memiliki layanan bebas bayar [25], mudah untuk dioperasikan [26] dan dibangun karena pengembangan W3School ditujukan untuk berbagi ilmu dan tidak untuk mencari keuntungan secara financial [25]. Maka, dalam bidang Pendidikan pemanfaatan sarana dan layanan pada situs W3School lebih tinggi dibandingkan dengan situs yang lain karena didiukung oleh ITSB (Intelligent Tutoring System Authoring Tool) yaitu sebuah sistem pendidikan tutor cerdas bagi peserta didik [27].

Dari data google trend juga diperoleh kategori keminatan masyarakat berdasarkan Business \& Industrial dari masing-masing Website pada kurun waktu 5 tahun terakhir diperoleh (Gambar4) 


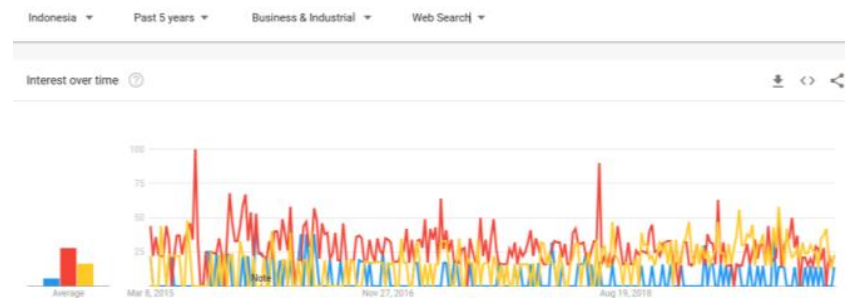

Gambar 4. Google Trend by Business \& Industrial Sumber: Perbandingan Website Google trends by Business \& Industrial[24]

Kesimpulan google trend dikembangkan sesuai hasil grafik dan didukung oleh literasi sebagai berikut:

1) Pada kategori Business \& Industrial Website yang paling sering digunakan adalah web site W3Schools dengan jumlah responden sejumlah 7.956. Situs W3school dibangun untuk pembelajaran dan pihak pengembang tidak mengambil pendapat atau biaya dari kegiatan di website, tidak memberikan file transfered, memberikan online compiler, dan segala sesuatu yang disediakan di website [22].

2) Website kedua dengan kategori Business \& Industrial paling sering digunakan adalah Website Udemy dengan jumlah responden 5.882. Pada situs Udemy menduduki peringkat kedua, karena memiliki layanan yang komplek, dapat melakukan develop project untuk kegiatan industry atau bisnis, terdapat guide atau instruktur hingga akhir project. Namun, situs Udemy berbayar dengan sharing fee kepada instruktur sebesar 50\% [28].

3) Website codecademy merupakan Website dengan jumlah paling rendah pada kategori Business \& Industrial dengan total pengunjung 3.258 responden.

Dari data google trend juga diperoleh kategori keminatan masyarakat berdasarkan Computers \& Electronics dari masing-masing Website pada kurun waktu 5 tahun terakhir (lihat Gambar 5).

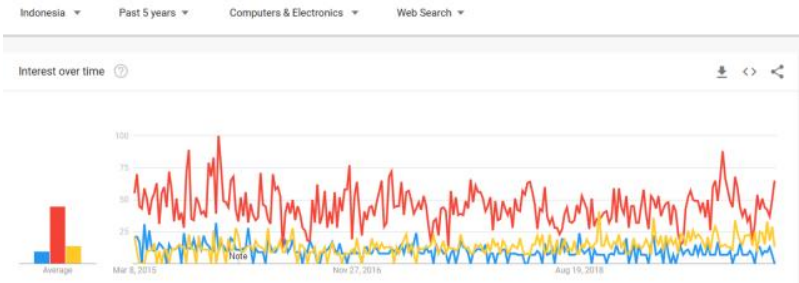

Gambar 5. Google Trend by Computer\&Electronic

Sumber: Perbandingan Website Google trends by Computer\&Electronic [24]

Kesimpulan google trend dikembangkan sesuai hasil grafik dan didukung oleh literasi sebagai berikut:

1) Pada kategori Computers \& Electronics Website yang paling sering digunakan adalah web site W3Schools dengan jumlah responden sejumlah 11.713. Dari sisi penggunaan website sesuai dengan data statistic, situs W3schools dapat diakses oleh beberapa browser yang familiar antara lain: a). Chrome; b). Edge/IE; c). Firefox; d). Safari; dan e). Opera. Hal ini menunjukkan bagaimana tingkat popularitas website W3school juga didasari oleh dukungan dari website optimalizer dengan banyaknya jenis browser yang dapat digunakan dan trends of browser usage dapat diakses oleh publik [29].

2) Website kedua dengan kategori Computers \& Electronics paling sering digunakan adalah Website Udemy dengan jumlah responden 3.532. Statistic trends of browser usage pada website Udemy tidak dapat diakses oleh publik.

3) Website codecademy merupakan Website dengan jumlah paling rendah pada kategori Computers \& Electronics dengan total pengunjung 2.576 responden.

Dari hasil pengamatan melalui google trends dapat diperoleh bahwa online coding course yang paling mendapat minat dari masyarakat, yang dikomparasi dari seluruh kategori di lima tahun terakhir, menghasilkan salah satu website paling populer, yaitu situs W3School. Data ini akan dikomparasi dengan hasil observasi pada peserta didik dengan dua keahlian atau background yang berbeda. Dari hasil observasi diperoleh beberapa hasil analisis antara lain:

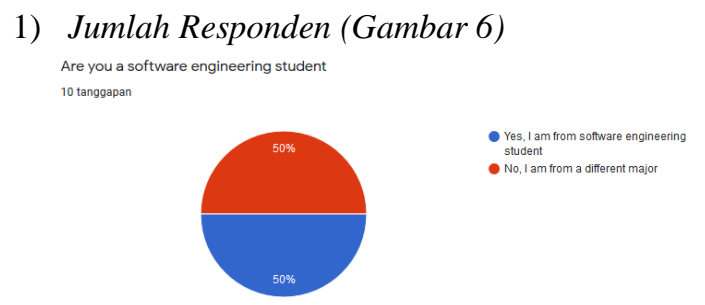

Gambar 6. Jumlah Responden Melalui Google Form Sumber: Analisis Hasil Uji Coba melalui Google Form [30]

Pengambilan jumlah sampel dilakukan dengan observasi pada dua kelompok kategori yang berbeda, yaitu 5 responden dari kelompok expert dan 5 responden dari kelompok dengan beda bidang keahlian. Dua kelompok diberikan beberapa poin pertanyaan dengan berpedoman menggunakan 5Es, yaitu sebagai berikut: $a$. Effective: $b$. Efficient; c. Engaging; d. Error Tolerant; dan e. Easy to Learn [20]. Ke lima poin dijabarkan dalam bentuk angket dengan tools Google Form.

2) Minat User

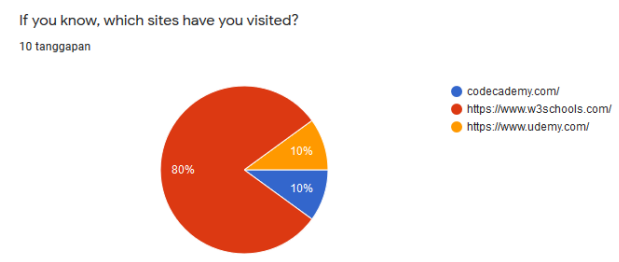

Gambar 7. Hasil Uji Coba melalui Google Form Sumber: Analisis Hasil Uji Coba melalui Google Form [30]

Analisis minat pada user dijabarkan menjadi tiga kategori yaitu (Gambar 7): a. Minat untuk mengunjungi situs codecademy; b. Minat untuk mengunjungi situs 
W3school; dan c. Minat untuk mengunjungi Udemy. Dari data diatas, dapat dijabarkan sebuah analisis yaitu:

- Dari data diatas diperoleh bahwa minat user dalam melakukan kunjungan terhadap situs online coding course sangat tinggi pada situs https://www.w3schools.com/ dengan presentase sebesar $80 \%$.

- Diposisi berikutnya dengan hasil presentase yang sama yaitu $10 \%$ dengan situs https://www.codecademy.com/ dan https://www.udemy.com/

- Hasil dari ceklis angket, menunjukkan kecenderungan penggunaan Situs W3school sebagai layanan online coding course dengan jumlah poin ketercapaian 132 dari 180 poin, hal ini dikarenakan situs W3school memiliki akses yang gratis, warna web yang cerah dengan warna dominan hijau, banyak sekali open project yang dapat dicoba, serta W3school memiliki syntax yang dapat dicopy clipboard kemudian diterapkan pada project yang sedang dibuat.

- Pada posisi kedua dengan nilai poin ketercapaian 110 dari 180 adalah situs codecademy,situs ini memiliki kemiripan dengan situs W3school, namun situs codecademy ini tidak memiliki banyak syntax yang dapat dicopy clipboard pada project yang sedang berlangsung, dan codecademy ini juga bersifat trial dan berbayar.

- Pada posisi terakhir adalah situs Udemy, dengan nilai ketercapaian 109 dari 180. Situs Udemy sangat digemari kelompok expert karena fasilitas didalamnya sangat detail, terdapat pula lecturer atau guide didalam situs, namun hal ini tidaklah menarik minat kelompok sebagian non expert karena situs ini berbayar dan tidak terdapat free trial coding seperti fasilitas yang diberikan oleh situs codecademy.

\section{3) Served Service}

Dari tahapan-tahapan yang telah dilakukan, maka hasil dari layanan pada masing-masing website dan berpedoman pada 5Es (a. Effective: $b$. Efficient; $c$. Engaging; d. Error Tolerant; dan e. Easy to Learn) dapat disimpulkan sebagai berikut:

$$
\text { TABEL II }
$$

SERVA SERVICE

\begin{tabular}{|c|c|c|c|}
\hline No & Platform & Served Service & Limitations \\
\hline 1 & W3School & $\begin{array}{l}\text { - } \text { Akses terbuka } \\
\text { - Tidak ada biaya } \\
\text { pelatihan } \\
\text { - Didukung oleh } 11 \\
\text { Bahasa } \\
\text { pemrograman } \\
\text { - Terdapat Quiz } \\
\text { - Menyediakan } \\
\text { template syntax. } \\
\text { - Terdapat web } \\
\text { template } \\
\text { - Didukung Bahasa } \\
\text { dari } 108 \text { Negara }\end{array}$ & $\begin{array}{l}\text { - } \text { Tidak dapat } \\
\text { melakukan } \\
\text { upload } \\
\text { project. } \\
\text { - } \text { Tidak dapat } \\
\text { download } \\
\text { project. } \\
\text { - Sertifikat } \\
\text { Berbayar. }\end{array}$ \\
\hline
\end{tabular}

\begin{tabular}{|c|c|c|c|}
\hline & & $\begin{array}{l}\text { - Warna website } \\
\text { Hijau yang berarti } \\
\text { menunjukkan } \\
\text { inovasi dari } \\
\text { teknologi. } \\
\text { - Responsive Website } \\
\text { pada semua gadget. } \\
\text { - Terdapat Exercise } \\
\text { disertai } \\
\text { jawabannya. } \\
\text { - Terdapat forum } \\
\text { diskusi pada } \\
\text { http://w3schools.in } \\
\text { visionzone.com/ } \\
\text { Terdapat Report } \\
\text { Error pada } \\
\text { help@ w3schools.c } \\
\text { om } \\
\text { Website sangat } \\
\text { mendukung pada } \\
\text { beberapa bahasa } \\
\text { pemrograman } \\
\text { khususnya pada } \\
\text { Website } \\
\text { Environment. }\end{array}$ & \\
\hline No & Platform & Served Service & Limitations \\
\hline 2 & Udemy & $\begin{array}{l}\text { - Terdapat Guide } \\
\text { atau instruktur. } \\
\text { - Terdapat web } \\
\text { development } \\
\text { (berbayar) } \\
\text { - Selain web } \\
\text { environment, } \\
\text { Udemy juga } \\
\text { menyediakan } \\
\text { pelatihan tentang } \\
\text { AI, 3D image, } \\
\text { desain, IT/ } \\
\text { Software, } \\
\text { photography, dst. } \\
\text { (Berbayar) } \\
\text { - Terdapat Udemy } \\
\text { for business dan } \\
\text { personal. } \\
\text { - Didukung Bahasa } \\
\text { dari } 8 \text { Negara } \\
\text { - Responsive Website } \\
\text { pada semua gadget. } \\
\text { - Warna pada } \\
\text { website kombinasi } \\
\text { ungu dengan putih } \\
\text { ingin memunculkan } \\
\text { kesan simple dan } \\
\text { minimalis. }\end{array}$ & $\begin{array}{ll}\text { - } & \text { Akses } \\
\text { berbayar } \\
\text { pada semua } \\
\text { fitur } \\
\text { - } \quad \text { Sertifikat } \\
\text { berbayar. } \\
\text { - Tidak } \\
\text { terdapat trial } \\
\text { mode untuk } \\
\text { pemula atau } \\
\text { siswa. }\end{array}$ \\
\hline No & Platform & Served Service & Limitations \\
\hline 3 & $\begin{array}{l}\text { Codecade } \\
\text { my }\end{array}$ & $\begin{array}{l}\text { Terdapat fitur } \\
\text { codecademy for } \\
\text { business dan } \\
\text { personal. }\end{array}$ & $\begin{array}{l}\text { - Terdapat fitur } \\
\text { yang berbayar. } \\
\text { - } \quad \text { Tidak dapat } \\
\text { melakukan }\end{array}$ \\
\hline
\end{tabular}




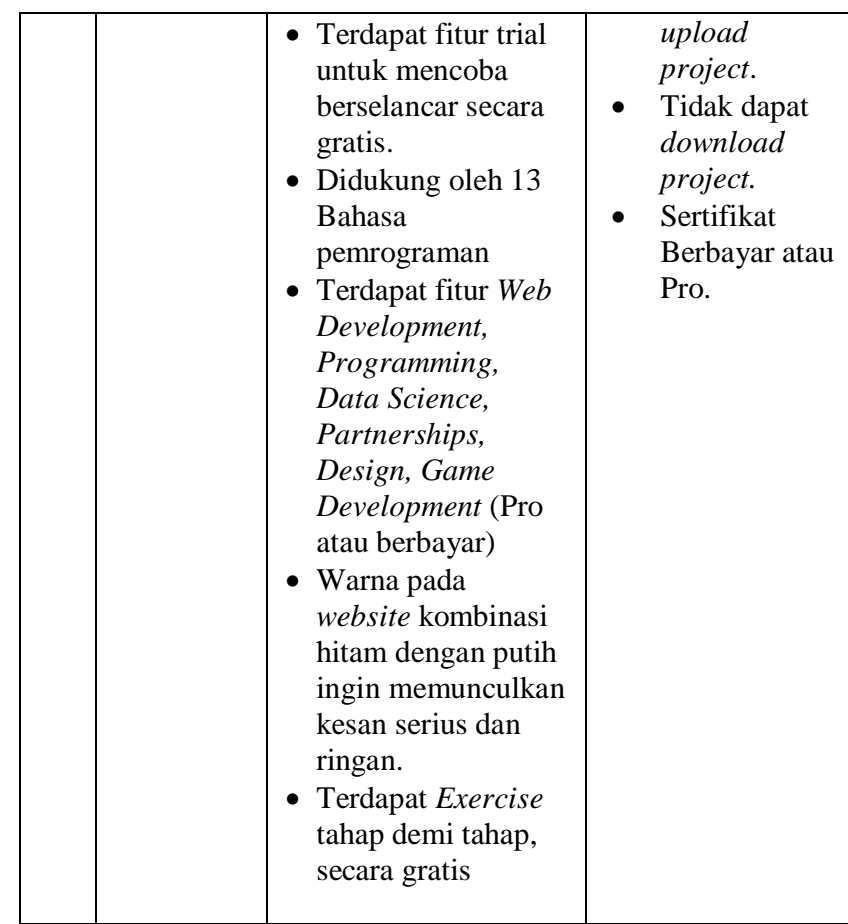

\section{4) Data Analyze}

Data yang telah diambil secara acak dari koresponden, nantinya akan diukur dengan skala Guttman. Data yang dihasilkan akan bernilai positive jika bernilai 1 dan negative jika bernilai 0. Data akan diukur dengan mencari rata-rata dari koresponden dan jumlah skor per item [31] dengan pengukuran analisis data menggunakan rumus sebagai berikut:

$$
\begin{aligned}
& \bar{X}=\frac{\sum \bar{x} \text { [koresponden] }}{\Sigma \text { Skor Item }} \\
& \bar{X}=\text { Skala rata rata per koresponden } \\
& \Sigma \bar{x} \text { [koresponden] = Nilai total } \\
& \Sigma \text { item = Jumlah item per skala }
\end{aligned}
$$

Skala hasil perhitungan dilakukan menggunakan skala Guttman. Skala Guttman digunakan untuk pengukuran data yang bersikap interval dan rasio untuk memperoleh nilai tegas. Skala Guttman dalam penelitian ini adalah nilai 1 dan 0 , dengan deskripsi dibawah ini:

- Nilai 1 : Terdapat fasilitas dalam Website

- Nilai 0 : Tidak terdapat fasilitas dalam Website

TABEL III

HASIL ANALISIS DATA

\begin{tabular}{|l|c|c|c|}
\hline \multicolumn{1}{|c|}{ Category } & Codecademy & W3School & Udemy \\
\hline $\begin{array}{l}\text { Effective (Respon } \\
\text { time) }\end{array}$ & 0.15 & 0.30 & 0.22 \\
\hline Efficient & 0.49 & 0.53 & 0.34 \\
\hline Engaging & 0.35 & 0.36 & 0.36 \\
\hline Error Tolerant & 0.2 & 0.4 & 0.1 \\
\hline Easy to Learn & 0.9 & 0.9 & 0.6 \\
\hline
\end{tabular}

\begin{tabular}{|l|c|c|c|}
\hline Category & Codecademy & W3School & Udemy \\
\hline Total Skor & 1.10 & 1.32 & 1.09 \\
\hline
\end{tabular}

\section{KESIMPULAN}

Penggunaan teknologi sebagai sumber belajar adalah salah satu dari komitmen merdeka belajar, merdeka belajar tanpa batas waktu dan batas sumber belajar. Sebagaimana dibahas dalam penelitian ini, bahwa sistem informasi yang dikembangkan khususnya bagi proses pembelajaran mendapat minat yang cukup tinggi dari elemen masyarakat. Salah satu online coding course yang memiliki rate tertinggi adalah $\mathrm{W} 3$ school. Dengan beberapa fitur online compiler meliputi berbagai bahasa pemrograman yang dimiliki, memenuhi kriteria sistem informasi lima E yaitu 5E yaitu: a. Effective; b. Efficient; c. Engaging; d. Error Tolerant; serta e. Easy to Learn, dan membuka kemudahan akses tanpa prasyarat yang sukar, membuat situs W3school diminati para peserta didik sebagai website paling sering dan mudah untuk dikunjungi sebagai sumber belajar bahasa pemrograman. Online Coding Course sangat diminati karena mampu menjawab keterbatasan jarak, ruang, dan waktu sebagai suplemen pembelajaran pemrograman jarak jauh.

Hasil dari penelitian ini dapat digunakan acuan developer untuk memperhatikan sasaran dan market pada pengguna aplikasi, karena untuk online coding course peminat dari siswa SMK lebih mengarah pada akses yang gratis, dapat digunakan sebagai tutorial pembangunan aplikasi, dan mendapatkan course secara bertahap.

\section{REFERENSI}

[1] W. P. Dewa, N. Rofiah, And S. Nita, "Sistem Informasi Pembelaran Bahasa Pemrograman Java Menggunakan Metode Dao Dan Mvc Berbasis Web," Semin. Nas. Teknol. Inf. Dan Komun., Vol. 0, Pp. 1-6, 2018.

[2] L. Joni, "Media Pembelajaran Bahasa Pemrograman C++," Jurusan Manajemen Informatika, Ftk, Undiksha, 1395.

[3] B. Mccane, "Introductory Programming With Python Curriculum," Python Pap. Monogr., Vol. 1, Pp. 1-11, 2015.

[4] R. Nixon, Learning Php, Mysql \& Javascript With Jquery, Css \& Html5. .

[5] Reksoadmodjo N T, Pengembangan Kurikulum Pendidikan Teknologi Dan Kejuruan. Pt Revika Aditama, 2010.

[6] A. K. Firman, H. Mustafidah, J. Raya, And D. Purwokerto, "Analisis Korelasi Pemanfaatan Internet Terhadap Prestasi Mahasiswa Teknik Informatika Universitas Muhammadiyah Purwokerto ( Correlation Analysis Of The Internet Use And The In Muhammadiyah University Of Purwokerto )," Juita (Jurnal Inform. Ump, Vol. Iii, No. November, Pp. 63-69, 2014.

[7] S. Suwarsito And H. Harjono, "Pemanfaatan Edukasi-Net Dalam Pencarian Sumber Belajar Melalui Akses Internet," Juita (Jurnal Inform. Ump, Vol. I, No. 2, Pp. 59-63, 2010.

[8] D. Surani, "Studi Literatur: Peran Teknolog Pendidikan," 2019, Vol. 2, No. 1, Pp. 456-469.

[9] A. Kurniawan And H. Mustafidah, "Analisis Dampak Pemanfaatan Website Desa Dalam Perkembangan Ekonomi Warga Kecamatan Kalibagor ( The Impact Of Website Used Analysis In Economic Development At Kalibagor Resident )," Juita (Jurnal Inform. Ump, Vol. Iv, Pp. 48-57, 2016.

[10] Pusvyta Sari, "Memotivasi Belajar Dengan Menggunakan ELearning," Ummul Quro, Vol. 6, No. Jurnal Ummul Qura Vol Vi, No 2, September 2015, Pp. 20-35, 2015. 
[11] Henri Septanto, "Elearning Menggunakan Edmodo Sebuah Aplikasi Pembelajaran Berbasis Web Pada Kelas Shift Di Stmik Bina Insani,” Bina Insa. Ict J., Vol. 2, No. 2, P. 129, 2015.

[12] Psmk Kemdikbud, "Ki Dan Kd Smk/Mak (Perdirjen Dikdasmen No. 464/D.D5/Kr/2018)," 2019.

[13] Jerrad, "11 Places To Learn To Code Online," 2019. [Online]. Available: Https://Www.Whatsthehost.Com/Learn-To-CodeOnline/.

[14] J. H. Sharp, "Using Codecademy Interactive Lessons As An Instructional Supplement In A Python Programming Course," Inf Syst. Educ. J., Vol. 17 (3), No. 1, Pp. 20-25, 2019.

[15] M. Lulu Latif, "Pengaruh Penggunaan Website Www.W3schools.Com Terhadap Prestasi Belajar Mata Pelajaran Pemrogaman Web Di Smk Negeri 1 Bawang,” J. Pendidik. Tek. Inform., Pp. 1-6.

[16] G. R. Agrawal, "Udemy- A Virtual Learning Environment," Vol. 68, No. 9, Pp. 1141-1147, 2020.

[17] R. Kohavi And R. Longbotham, "Online Controlled Experiments And A/B Testing," Encycl. Mach. Learn. Data Min., No. January, 2016.

[18] “A/B Testing." [Online]. Available: Https://Devopedia.Org/A-BTesting.

[19] Data Scienece Assn, "The Ultimate Guide To A / B Testing What' S In The Ebook? What Is Unbounce?,".

[20] W. Quesenbery, "Dimensions Of Usability: Defining The Conversation, Driving The Process," Proc. Usability Prof. Assoc. Conf. Ubiquitous Usability, 2003.

[21] T. Burns, Y. Gao, C. Sherman, A. Vengerov, And S. Klein, "Information Systems Education Journal," Inf. Syst. Educ. J., Vol. 12, No. 1, Pp. 4-16, 2014.

[22] V. Pateriya, S. Salegaonkar, J. Shah, S. Shivale, And R. Diwate, "A Survey On E-Resource System Vivekkumar," Int. J. Innov. Res. Comput. Commun. Eng. (An Iso Certif. Organ., Vol. 4, No. 2 , 2016.
[23] A. W. Paper, "Meeting The Upskilling Demands Of The Singapore Workforce Through Moocs," Pp. 1-39.

[24] Google Trend, "Compare For Website: Codecademy; W3school; Dan Udemy.," 2020. [Online]. Available: Https://Trends.Google.Com/Trends/Explore?Date=Today $\mathrm{Y} \& \mathrm{Geo}=\mathrm{Id} \& \mathrm{Q}=\% 2 \mathrm{fm} \% 2 \mathrm{f} 0 \mathrm{kfx} 9 \mathrm{cl}, \% 2 \mathrm{fm} \% 2 \mathrm{f0g} 48 \mathrm{fl}, \% 2 \mathrm{fm} \% 2 \mathrm{f} 0 \mathrm{~h} 3$ rj36.

[25] Siti Nurbaya, "Mengapa Situs Seperti W3schools Bisa Bebas Biaya," November 2018, 2018. [Online]. Available: Https://Id.Quora.Com/Mengapa-Situs-Seperti-W3schools-BisaBebas-Biaya-Dengan-Semua-Fitur-Dan-Layanan-Yang-AdaSedangkan-Situs-Lain-Memerlukan-Akun-KeanggotaanBerbayar-Untuk-Menikmati-Fitur-Seperti-Itu. [Accessed: 09-Mar2020].

[26] Firmansyah R, "Belajar Coding: Apa Yang Harus Dipelajari? Dan Website Belajar Pemrograman," Desember 2019, 2019. [Online]. Available: Https://Www.Jagoanhosting.Com/Blog/Belajar-Coding/. [Accessed: 09-Mar-2020].

[27] M. Z. Shaath Et Al., "Css-Tutor: An Intelligent Tutoring System For Css And Html Mariam,” Int. J. Acad. Res. Dev., Vol. 2, No. 1, P. January 2017; Page No. 94-99, 2017.

[28] L. Wai, "Data Science At Udemy: Agile Experimentation With Algorithms," Ftc 2016 - Proc. Futur. Technol. Conf., No. December, Pp. 355-360, 2017.

[29] W3school, "Browser Statistics," 2020. [Online]. Available: Https://Www.W3schools.Com/Browsers/Default.Asp. [Accessed: 09-Mar-2020].

[30] "Respons Google Form," 2020. [Online]. Available: Https://Docs.Google.Com/Forms/D/E/1 faipqlseyst5th6yvstskm26 zb7jk4kpin85ns5plv-4xd9t1tj641g/Viewform?Usp=Sf_Link. [Accessed: 17-Mar-2020].

[31] D. Derisma, "Analyzing User Experience Of Website For The Learning Of Programming Language," J. Edukasi Dan Penelit. Inform., Vol. 6, No. 1, P. 1, 2020. 